\title{
Improving poultry meat and sales channels to address food safety concerns: consumers' preferences on poultry meat attributes
}

Improving poultry meat and sales channels

\author{
Dikky Indrawan
}

Department of Social Sciences, Business Economics, Wageningen University and Research, Wageningen, Netherlands and School of Business, IPB University, Bogor, Indonesia

Accesstia Christy

Department of Social Sciences, Business Economics, Wageningen University and Research, Wageningen, Netherlands and VIDA Bekasi, Javara Academy, Bekasi, Indonesia, and Henk Hogeveen

Department of Social Sciences, Business Economics, Wageningen University and Research, Wageningen, Netherlands

\begin{abstract}
Purpose - This study explains Indonesian consumers' choice of poultry meat attributes and the willingness to pay (WTP) for these attributes using a discrete choice experiment.

Design/methodology/approach - The survey was conducted for the traditional and modern channels and involved a sample of 440 respondents in the Greater Jakarta area. A discrete choice experiment was employed as the study framework and in designing the questionnaire. A multinomial logistic regression analysis was used to evaluate consumers' preference for poultry attributes in modern and traditional channels.

Findings - Consumers preferred warm poultry meat, government certification and product information labeling on poultry meat. The WTP for warm poultry meat was the highest, which is indicating that freshness is crucial for consumers to ensure quality. Moreover, consumers had more trust in government certification than private certification for food safety and were willing to pay more for product information labeling on poultry meat.

Practical implications - The government can use the model as a decision support to improve poultry meat quality at sales channels in Indonesia including to close sales channels where sick poultry are sold and thus address food safety concerns caused by the avian influenza outbreak.
\end{abstract}

C Dikky Indrawan, Accesstia Christy and Henk Hogeveen. Published by Emerald Publishing Limited. This article is published under the Creative Commons Attribution (CC BY 4.0) licence. Anyone may reproduce, distribute, translate and create derivative works of this article (for both commercial and non-commercial purposes), subject to full attribution to the original publication and authors. The full terms of this licence may be seen at http://creativecommons.org/licences/by/ 4.0/legalcode

All authors are thankful to Asep Rakhmat for organizing the interviews.

Funding: DI and AC are funded by an Indonesian Endowment Fund for Education (LPDP) scholarship. The funder played no role in this study.

Author Contributions: DI and AC designed the study, collected and analyzed the data and drafted the manuscript. The remaining authors provided input on the study's design, helped interpret the study result and critically revised the manuscript. All authors read and approved the final manuscript.

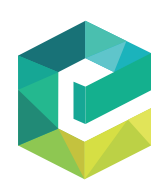

British Food Journa Vol. 123 No. 13,2021 pp. 529-546 Emerald Publishing Limited 0007-070X DOI 10.1108/BFJ-04-2021-0362 
BFJ

123,13

Originality/value - This study shows that understanding the WTP for poultry meat attributes enables the government to control the poultry sales channels and stimulates producers to supply the market with a safer poultry meat quality using the price mechanism.

Keywords HPAI, Poultry meat attributes, Non-food safety attribute, Food safety attribute, Willingness to pay, Discrete choice experiment

Paper type Research paper

\section{0}

\section{Introduction}

Food safety challenges including microbial hazards, such as avian influenza, Salmonella, Campylobacter, Listeria monocytogenes, Clostridium perfringens and E. coli $\mathrm{O} 157$ (Mead, 2004; Meredith et al., 2013; Yeung and Morris, 2001), and chemical hazards such as formaldehyde, aflatoxins and veterinary drugs (Fardiaz et al., 2011; Kiilholma, 2008; Sparringa, 2014) are public health concerns. A food safety challenge hit the Indonesia poultry meat industry after the highly pathogenic avian influenza (HPAI) H5N1 outbreak in 2005. HPAI H5N1 outbreak occurred because of a complex poultry chain structure with an interaction between traditional and modern sales channels where sales channels where sick poultry are sold exist (Indrawan et al., 2018a). A poultry sales channel refers to the routes and chains used to sell poultry meat to markets and end users. A sales channel where sick poultry are sold allows farmers and traders to sell their susceptible and disease-infected poultry. These sales channels are multisales channels used by the poultry actors to sell their different quality products to different consumers following its sales channel. Meats with low food safety levels are sold in the traditional channel. This channel is known for the existence of the sick poultry market selling suspected HPAI H5N1 poultry (Indrawan et al., 2018a). Unlike low food safetylevel meat, meats with high food safety level are sold in the modern channel. Three factors can be identified as the main sources of the food safety challenge emerging from the HPAI H5N1 outbreak: First, the current food safety control systems in Indonesia are weak (Bahri, 2008; Hariyadi, 2008). Second, some consumers prefer to buy poultry meat from the traditional channel with low food safety levels (Indrawan et al., 2018a; Indrawan et al., 2018b; Muladno and Thieme, 2009). Third, price and freshness presentation when purchasing poultry are important to most consumers (Daryanto et al., 2014; Indrawan et al., 2018a, 2018b; Indrawan et al., 2018b). These reasons suggest that Indonesian consumers' preferences for poultry meat attributes are not related to food safety.

Imposing control on the producers or consumers in the poultry market will help the government reduce food safety problems (Indrawan and Daryanto, 2020). After the outbreak of avian influenza in 2005, government efforts to overcome low safety meat problems by increasing controls for live birds entering the traditional channel were not successful, because the consumers still prefer purchasing their poultry meat from the traditional channel (Muladno and Thieme, 2009). The poultry meats they buy in this channel were in the form of whole birds, which were slaughtered early in the morning (Daryanto et al., 2014; Indrawan et al., 2018a). Sellers kept selling these low-safety meats, because of consumers' demand. Thus, changing consumers' preferences to reduce unsafe poultry meat was suggested to increase poultry meat quality and safety (Indrawan et al., 2018a). This is because the consumers' level of safety awareness influences the trade activity in food markets and retails, which should be considered to improve food safety for public health.

The improvement of food safety and quality is a critical factor in reducing food safety incidents (Grunert et al., 2004; Grunert, 2005; Scallan et al., 2011; Scott, 2003). Reducing the demand for poultry meat bought from unsafe sales channels is one key to overcoming the food safety challenge because it will pull the market toward safer production processes. Changes in demanded meat quality will incentivize farmers to apply biosecurity practices in 
protecting their poultry health and quality. Thus, if the government decides to raise poultry meat's food safety level, consumers must recognize this initiative. Moreover, knowing whether they are willing to pay a higher food safety level is also critical. The producers will look at the consumers' responses toward government intervention. The poultry chain producers produce a wide variety of poultry meat quality without any intervention, following the consumers' heterogeneous poultry meat preferences (Verbeke and Viaene, 1999). Therefore, a new poultry meat safety standard has to match the consumers' demand for poultry actors to produce higher-quality poultry meat.

Understanding consumers' preferences on food attributes and willingness to pay (WTP) in buying poultry meats is important to raise poultry meat safety. Consumers rely on the experienced quality and credence attributes of a product as their quality cue when making buying decisions (Grunert et al., 2004; Grunert, 2005; Issanchou, 1996). These attributes can consist of nonfood safety attributes (e.g. freshness, taste (sensory), environment, animal welfare) and food safety attributes (e.g. certification, product information label, country of origin). By evaluating consumers' WTP for these quality attributes, the government can develop food safety policies in the multisales channels. Studies on nonfood safety attributes found that consumers rely on intrinsic cues (e.g. cut, color, fat) to evaluate a product (Grunert et al., 2004; Grunert, 2005), but the demands for intrinsic values of meat are heterogeneous and difficult to measure (Henchion et al., 2014). Studies on food safety attributes concluded that consumers do not easily evaluate food safety as a credence attribute. Instead, they tend to rely on the intrinsic and extrinsic cues to assume food safety (Grunert et al., 2004; Grunert, 2005; Angulo and Gil, 2007). Research on nonfood safety and food safety attributes concerning WTP for poultry meat is limited. For example, studies in the Indonesian context, such as Indrawan et al. (2018a), Indrawan et al. (2018b) and Muladno and Thieme (2009), identified the role of the freshness attribute in the poultry demand of Indonesian consumers, but they did not explore WTP for freshness as a nonfood safety attribute. These studies found that freshness for poultry meat in Indonesia is associated with the time of slaughter (early morning). The WTP for poultry meat with "country of origin" as a food safety attribute was evaluated in a 2010 meta-analysis (Cicia and Colantuoni, 2010). However, to the best of our knowledge, available research on the WTP for nonfood safety or food safety attributes for poultry meat in Indonesia such as Lestari et al. (2016) and Wahida et al. (2013) is limited. A related study in Southeast Asia focused on fresh food (Wongprawmas and Canavari, 2017). Therefore, this research's overall objective is to evaluate consumer preferences and WTP for poultry meat attributes in two sales channels in the Greater Jakarta area: the modern channel and the traditional channel.

Using a choice experiment in multisales channels that sell poultry meats, this study assesses consumer preferences and WTP for a set of poultry meat attributes. The paper analyzed consumers' preference for certain choice attributes (e.g. nonfood safety or food safety attributes) concerning their WTP. The choice experiment can provide insight into the consumer acceptability of attributes or the marginal utility of attributes (Probst et al., 2012; Rousseau and Vranken, 2013; Van Loo et al., 2011). Such an experiment determines an average or each consumer WTP for the poultry meat attributes. To obtain this overall objective, we included the following specific objectives: (1) to identify the attributes of poultry meat that consumers accept in different sales channels and (2) to examine the differences in WTP for poultry with identified acceptable meat attributes in different sales channels.

\section{Material and methods}

\subsection{Selection of poultry meat attributes and consumers' WTP}

As the first step in selecting poultry meat attributes, we studied the scientific literature on consumers' preferences and WTP for nonfood safety and food safety attributes to purchase

\section{Improving poultry meat and sales channels}


BFJ

123,13

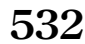

meat. The consumers' preferences and WTP for meat attributes have been an ongoing focus in many consumer studies (Grunert et al., 2004; Font-i-Furnols and Guerrero, 2014; Kehagia et al., 2007). Studies on meat quality attributes indicated several intrinsic (color, fat content and marbling) and extrinsic (price, origin and quality labels) cues as the most important factors in the consumers' intention to purchase food (Chamhuri and Batt, 2013; Font-i-Furnols and Guerrero, 2014; Grunert et al., 2004; Grunert, 2005; Henchion et al., 2014; Hoffmann, 2000; Kennedy et al., 2004; Verbeke and Viaene, 1999). Some studies examined these cues as quality attributes for poultry meat (Castellini et al., 2008; Fletcher, 2002; Samant and Seo, 2016; Verbeke and Viaene, 1999). In studying the WTP for food safety in the Indonesian poultry market, preliminary interviews with local experts identified freshness, food safety certification (FSC) and product information label as the three most important accessibility, search, experience and credence attributes. Freshness is the most important nonfood safety attribute in Indonesia and often refers to poultry meat quality (Chamhuri et al., 2015). Postslaughtered poultry meat handling defines the poultry meat freshness levels. Chamhuri et al. (2015), Daryanto et al. (2014) and Indrawan et al. (2018a) also acknowledged freshness as an important utility that differentiates poultry meat consumers in multisales channels. FSC is another important food safety attribute, providing a hygiene standard to prevent and reduce unacceptable risks of microbial and chemical hazards in food production (Lestari et al., 2016; Meuwissen et al., 2003; Wahida et al., 2013). Often, FSC as a food safety attribute cannot be separated from applying a product information label. Meanwhile, "product information label" as the food safety attribute plays an important role as an extrinsic cue for the consumers (Ortega et al., 2011; Wahida et al., 2013).

Previous studies on nonfood safety attributes showed that consumers often look at freshness as one of the most important poultry meat attributes when buying poultry meat in market outlets (Goldman and Hino, 2005; Goldman et al., 1999; Verbeke and Viaene, 2000). Different definitions of freshness have been used to examine consumers' behavior concerning poultry meat consumption (Bett et al., 2013; Martínez Michel et al., 2011; Maynard et al., 2003). In the context of the Indonesian poultry meat sector, freshness can be defined in three levels: warm, chilled and frozen (Daryanto et al., 2014; Indrawan et al., 2018a). Consumers perceived freshness as a signal for sensory quality (taste). A previous study showed that freshness is defined differently in Indonesia than in Western countries (Indrawan et al., 2018b), because many consumers prefer to buy poultry meat in the traditional channel, where the food safety level is lower than that in the modern channel (Muladno and Thieme, 2009). The reason is that consumers perceive the freshness of the warm (freshly cut) poultry meat in the traditional channel to be better than that of chilled poultry meat in the modern channel (Indrawan et al., 2018a; Indrawan et al., 2018b).

We studied the importance of food safety attributes for consumers by examining two main attributes: FSC and product information labeling. These attributes were not applied in most poultry sales channels in Indonesia. According to Meuwissen et al. (2003), FSC is as a certified assessment and approval by an accredited party on food safety standards. Certification is essential for improving of the safety of poultry meat (Souza et al., 2015), and several studies have considered FSC as a meat quality attribute (Lestari et al., 2016; Loureiro and Umberger, 2007; Ortega et al., 2011; Wahida et al., 2013; Wu et al., 2016). FSC provides a hygiene standard and is supported by swift internalization in the food industry; hence the demand for a public or private FSC has increased considerably (Meuwissen et al., 2003; Trienekens and Zuurbier, 2008). Thus, many studies have examined the WTP for FSC (Lestari et al., 2016; Ortega et al., 2011; Owusu-Sekyere et al., 2014; Wahida et al., 2013; Wu et al., 2016). Other studies on FSC revealed that many consumers have less confidence in the government to guarantee food safety due to past food safety incidents. However, private FSC provides higher quality, safety and traceability levels than government regulations (Albersmeier et al., 2009; Qijun and Batt, 2016; Simmons, 2010). A study on WTP for third- 
party FSC met the consumers' approval (Ortega et al., 2011). Although many food safety systems were established in the Indonesian poultry meat chain, FSC implementation was limited because of inadequate monitoring (Bahri, 2008; Hariyadi, 2008).

As an important food safety attribute, alongside FSC, a product information label provides information about the product on a label attached to the product package. Many food safety studies paid attention to product information labeling because such a label is a cue of the meat quality (Stranieri and Banterle, 2015; Verbeke and Ward, 2006; Wahida et al., 2013) and influences consumers' meat-buying preferences (Font-i-Furnols and Guerrero, 2014; Makanyeza et al., 2016). Product information labeling, when provided alone, does not increase consumers' utility significantly. However, this attribute will increase consumers' utility when provided together with a traceability standard (Ortega et al., 2011). Many studies have shown that consumers are willing to pay more for food products with a specific credence attributes label (Hu et al., 2011; Kehlbacher et al., 2012; Van Loo et al., 2011; Wahida et al., 2013). Another study has demonstrated that product information labeling can signal product quality from FSC because consumers have more trust in certified labeling (Schleenbecker and Hamm, 2013).

\subsection{Design of the choice experiment for poultry meat}

The choice experiment in this study was based on Lancaster's (1966) consumer theory, which states that consumer choice (maximizing utility) is directed toward combinations of product attributes rather than goods. The choice experiment is combined with the random utility theory that describes the utility $\mathrm{U}$ of an alternative as the sum of observed and unobserved components (McFadden, 2001).

We used a randomized choice-based conjoint research design that requires respondents to choose rather than rank or rate products. The randomized choice-based conjoint research design contained four suitable attributes for a local situation in the Greater Jakarta area Table 1 shows that the final shortlisted attributes were freshness (three levels), FSC (three levels), label (two levels) and price (three levels). For freshness, warm represents poultry meat that was recently slaughtered, whereas chilled and frozen represent a longer time process from slaughter to storage and/or markets. Chilled meat is meat that has been processed at temperatures higher than the meat freezing point but lower than $10^{\circ} \mathrm{C}$. Frozen meat is meat that has been processed by freezing the muscle tissue after it has been slaughtered. In FSC, we used the providers instead of certification items (e.g. brand, expiry date, country of origin and slaughtered date), that is, government providers (e.g. good slaughtering practices by certification of veterinary control) and private providers (e.g. Indonesian National Standard

\begin{tabular}{ll}
\hline Attribute & Attribute level \\
\hline Freshness & Warm poultry \\
& Chilled poultry \\
Food safety certification (FSC) & Frozen poultry \\
& Government \\
Label (production date, producers name and certification types) & Private \\
Price: $(€ /$ kg poultry) & No-certification \\
& Yes \\
& No \\
& 2.11 \\
& 2.46 \\
& 2.81
\end{tabular}

Note(s): $1 €=14,231$ IDR
Improving poultry meat and sales channels

533 
BFJ 123,13

\section{4}

Table 2 .

Example of choice set in the questionnaire for consumers who purchase poultry meat (per kg) and hazard analysis and critical control points) to examine the consumer trust in the provider if the FSC applied. Moreover, we used two levels to explore consumers' preference for information labels: with a label or without a label. The information label is defined as an information label that is used to confirm the authenticity and certification of a product. It ensures product safety and traceability. We used the attribute price to calculate the WTP for poultry meat attributes and other attributes to examine their utility. The price attribute consisted of three levels, based on the minimum, mean and maximum price per kilogram poultry in January-September 2016, according to the broiler poultry price at the Poultry Farmer Association website (PINSAR, 2016). The levels for the other three attributes were based on scientific literature as described earlier. This approach followed the methodology of Van Loo et al. (2011).

Using a full factorial design (Kuhfeld, 1997), we designed the combination of attributes and levels to be balanced and orthogonal, resulting in 54 possible choice sets (i.e. $3^{3} 2^{1}$ ). We considered the number of choices too overwhelming for one respondent to answer; thus, a fractional factorial design is used to reduce each respondent's number of choices (Wu et al., 2016). Using the random option, we sampled the profiles (randomly, with replacement) from the thousands of possibilities and placed them into choice sets. Overlap can and will occur in such design; therefore no two profiles were permitted within a choice set that was identical on all attributes (Chrzan and Orme, 2000). In addition, many level combinations between the attributes FSC and label were excluded, potentially resulting in imbalances and dependencies in the design. Therefore, we used D-efficiency to construct an orthogonal design, so that every pair of levels occurs equally across all the pairs of factors in each design (Kuhfeld, 2005). The questionnaires were computer-generated using Sawtooth Software (Lighthouse Studio version 9.2.0) to obtain 13 choice sets. Respondents were randomly offered different versions of choice sets (Chrzan and Orme, 2000). Depending on their response regarding how poultry was bought (per kilogram or as whole chicken), prices were provided as a price per kilogram or a price for a whole chicken (see Table 2).

Besides the choice set, the questionnaire contained some additional questions to retrieve information on the respondents' sociodemographic circumstances. Closed questions were asked about the age group, educational level, gender, income group and place of residence. An open-ended question was asked about consumers' awareness of food hazards to obtain information about the respondents' knowledge about the safety of poultry. The respondents could choose multiple responses.

\subsection{Sampling and administration}

Surveys were conducted in the Greater Jakarta area because it is Indonesia's largest poultry production and consumption area. Following the Slovin (1960) method and considering a 5\% margin error with Jakarta's population of 28,019,545 in 2014 (Statistics-Bureau, 2016), we targeted a total of 400 respondents. The survey's sampling method used a quota-sampling model based on consumers' income classification in the Greater Jakarta area, and we obtained 440 respondents (Table 3). The quota sample was split over the modern market and

\begin{tabular}{llll}
\hline & \multicolumn{1}{c}{ A } & \multicolumn{1}{c}{ B } & C \\
\hline Freshness & Warm & Frozen & Neither of the options \\
Food safety certification (FSC) & Private & Government & \\
Product information label & No & Yes & \\
$\begin{array}{l}\text { Price }(€ / \text { kg poultry) } \\
\text { I would choose }\end{array}$ & 2.46 & 2.11 & \\
\hline
\end{tabular}




\begin{tabular}{|c|c|c|c|c|c|c|c|c|c|}
\hline \multirow[b]{2}{*}{$\begin{array}{l}\text { Expenditure per } \\
\text { month }\end{array}$} & \multicolumn{4}{|c|}{ Jakarta region $(57 \%)$} & \multicolumn{4}{|c|}{ Jakarta surrounding region $(43 \%)$} & \multirow{2}{*}{$\begin{array}{l}\text { Improving } \\
\text { poultry meat } \\
\text { and sales }\end{array}$} \\
\hline & $\begin{array}{c}\% \text { of } \\
\text { sample }\end{array}$ & $\begin{array}{l}\text { Wet } \\
\text { market }\end{array}$ & $\begin{array}{l}\text { Modern } \\
\text { market }\end{array}$ & $\begin{array}{c}\text { Street } \\
\text { vendor }\end{array}$ & $\begin{array}{l}\% \text { of } \\
\text { sample }\end{array}$ & $\begin{array}{l}\text { Wet } \\
\text { market }\end{array}$ & $\begin{array}{l}\text { Modern } \\
\text { market }\end{array}$ & $\begin{array}{l}\text { Street } \\
\text { vendor }\end{array}$ & \\
\hline $\begin{array}{l}\% \text { of sample } \\
\text { based on channel } \\
\text { market }\end{array}$ & & $30 \%$ & $30 \%$ & $40 \%$ & & $30 \%$ & $30 \%$ & $40 \%$ & channels \\
\hline$>€ 189.7$ & 13 & 10 & 10 & 13 & 27 & 15 & 15 & 21 & 535 \\
\hline$€ 147.6-189.7$ & 27 & 20 & 20 & 27 & 23 & 13 & 13 & 17 & \\
\hline$€ 105.4-147.6$ & 28 & 21 & 21 & 28 & 21 & 12 & 12 & 16 & \\
\hline$€ 63.3-105.4$ & 21 & 16 & 16 & 21 & 17 & 10 & 10 & 13 & \\
\hline$<€ 63.3$ & 11 & 8 & 8 & 11 & 12 & 7 & 7 & 9 & \\
\hline Total & & 75 & 75 & 100 & & 57 & 57 & 76 & \\
\hline \multicolumn{10}{|c|}{$\begin{array}{l}\text { Note(s): } 1 €=14,231 \text { IDR; The traditional sales channel consists of wet markets and street vendors. Quota sampling in the } \\
\text { Meanwhile, the modern sales channel is modern markets }\end{array}$} \\
\hline
\end{tabular}

traditional market (consisting of wet market and street vendor) based on where the respondents mainly shop for poultry meat. Therefore, the targeted respondents were the consumers who are buying poultry meat in each market.

Nine trained enumerators conducted the surveys. Each question was explained in a meeting and briefing session where all enumerators could give input. The questionnaire was pretested to 30 respondents in a pilot survey. In this pilot survey conducted at different locations, respondents answered the questionnaire on a tablet through an offline Sawtooth Software application (SSI Web 9.2.). There were no changes in the questionnaires. Finally, the survey was conducted using a tablet. Consumers were approached mainly in traditional and modern markets. However, interviewing the respondents in the marketplace was difficult due to limited time. Moreover, not everyone was willing to be interviewed at the market during their shopping activities. When necessary, the enumerators visited related neighborhoods and places where target consumers were expected to gather, such as schools. That is, most homemakers have more free time while waiting for their children at the schools.

\subsection{The probability estimation of a chosen attribute}

First, we modeled the probability of attributes using multinomial logit (MNL). The utility for the attributes is derived from the respondents' choices for the defined poultry meat alternatives consisting of different levels of the attributes. A specified level of utility was associated with any poultry meat alternative $j$ for any respondent $i$. Utility $(U)$ derived from any poultry meat alternative was determined by the freshness of poultry meat, the presence of FSC or the product information label as the poultry meat attributes (expressed in vector $Z$ ). The utility function of respondent's choice consists of a deterministic part and follows a predetermined distribution:

$$
U_{i j}=V\left(Z_{i j}\right)+\varepsilon\left(Z_{i j}\right)
$$

Consumers' choices between alternatives were a function of the following probability: the utility of respondent $i$ associated with a particular poultry meat product $j$ is higher than those of other alternatives. The relationship between the utility and attributes was assumed to be linear in the parameters and variables function. The error component of $Z i j$ is the random utility component, which consists of unobservable individual characteristics, estimation errors and unobserved attributes. The error term is a random stochastic component, implying that predictions cannot be made with certainty. The error term $(\varepsilon)$ was assumed to be identical and distributed independently by a Weibull distribution. Therefore, the probability 
BFJ 123,13

$\left(P_{i j}\right)$ of respondent $i$ choosing any specific poultry meat alternative $\mathrm{j}$ can be stated in terms of a logistic distribution, which takes the general form (where $C$ is the total number of choice alternatives):

$$
P_{i j}=\frac{\exp (V(Z i j))}{\sum_{i=1}^{C} \exp (V(Z i j))}
$$

The main assumption is that the alternative that offers the highest utility in the choice set $\left(c_{i}\right)$ consisting of $j$ options will be chosen by each individual $i$. Therefore, the probability of choosing alternative $j$ in the choice set is greater than or equal to the utilities of all other alternatives.

MNL was employed to analyze choice experiment data based on McFadden's (2001) model. The MNL model gives the probability that an individual $i$ chooses alternative $j$ of a choice set $\left(c_{i}\right)$. The model assumed that the consumers' taste is homogeneous and the random errors across the $j$ alternatives are distributed independently and identically. Thus, the maximum likelihood technique is used to provide an estimation of the MNL model.

The choice experiment was designed for participants to choose between two poultry meats (alternatives A and B) that carried different attributes and a no-buying scenario. The following utility function was used in the choice experiment design:

$$
\begin{aligned}
U_{i j}= & \beta_{0}+\beta_{1}+\beta_{2} \text { Warm_Fresh }_{i j t}+\beta_{3} \text { Chilled_Fresh }_{i j t}+\beta_{4} \text { Frozen_Fresh }_{i j t} \\
& +\beta_{5} \text { Government_Certification }_{i j t}+\beta_{6} \text { Private_Certification }_{i j t}+\beta_{7} \text { No_Certification }_{i j t} \\
& +\beta_{8} \text { Product_Label }_{i j t}+\beta_{9} \text { No_Product_Label }_{i j t}+\beta_{10} \text { Price }_{i j t}+\varepsilon_{i j t}
\end{aligned}
$$

where $N$ is the number of respondents, $t$ is the number of choice occasions; $\beta_{0}$ and $\beta_{1}$ are dummy variables indicating the selection of alternative $A$ or alternative $B$ with respect to the no-buy choice option (alternative C); Warm_Fresh Government_Certification $_{i j t}$, Private_Certification $i j t$, No_Certification $i j t$, Product_Label $i j t$ and No_Product_Label ${ }_{i j t}$ are dummy variables taking the value +1 if the product has the attribute, and 0 if it does not have the attribute; Price ${ }_{i j t}$ is the price for a package of $1 \mathrm{~kg}$ poultry meat. Therefore, using a choice experiment, we let the respondents choose the product profiles based on their understanding that all attribute levels are the same. We employed the MNL based on each market's choice experiment, because we have multisales channels, that is, modern and traditional.

\subsection{Estimation of willingness to pay of the poultry meat attributes}

As the follow-up from the choice experiment above, we calculated WTP in the modern and traditional sales channels. The mean WTP for each attribute was estimated by calculating the ratios between attribute utility ratio and the price utility ratio. Hence, the WTP for attributes is the price change associated with a change in a level of utility in a specified attribute, as indicated by Van Loo et al. (2011):

$$
\text { WTP Attribute }=\frac{\frac{\partial U i j t}{\partial \text { Attributelevel }}}{\frac{\partial U i j t}{\partial \text { Price }}}
$$

\section{Results}

Table 4 presents an overview of the respondents' sociodemographic information, per poultry sales channel. The majority of the respondents were female, as expected, because women 


\begin{tabular}{|c|c|c|c|c|}
\hline & Definition & $\begin{array}{c}\text { Modern channel } \\
\quad(N=117) \\
\text { In percentage }\end{array}$ & $\begin{array}{c}\text { Traditional channel } \\
(N=313) \\
\text { In percentage }\end{array}$ & $\begin{array}{l}\text { Improving } \\
\text { poultry meat } \\
\text { and sales }\end{array}$ \\
\hline \multirow[t]{5}{*}{ Age group } & 20-30 years old & 29.9 & 22.68 & channels \\
\hline & $31-40$ years old & 36.8 & 31.95 & \\
\hline & $41-50$ years old & 23.9 & 29.39 & \\
\hline & $51-60$ years old & 8.5 & 13.74 & 537 \\
\hline & More than 60 years old & 0.9 & 2.24 & \\
\hline \multirow[t]{4}{*}{ Educational level } & Primary & 0 & 6.71 & \\
\hline & Junior high school & 6 & 10.86 & \\
\hline & Senior high school & 53 & 54.95 & \\
\hline & University & 41 & 27.48 & \\
\hline \multirow[t]{2}{*}{ Gender } & Female & 92.3 & 97.76 & \\
\hline & Male & 7.7 & 2.24 & \\
\hline \multirow[t]{5}{*}{ Income group } & Less than $€ 63.3$ & 20.5 & 22.04 & \\
\hline & $€ 63.3-105.4$ & 25.6 & 19.81 & \\
\hline & $€ 105.4-147.6$ & 20.5 & 23.64 & \\
\hline & $€ 147.6-189.7$ & 6.8 & 11.18 & \\
\hline & More than $€ 189.7$ & 26.5 & 23.32 & \\
\hline \multirow[t]{2}{*}{ Place of residence } & Jakarta & 41 & 52.72 & \\
\hline & Greater Jakarta & 59 & 47.28 & \\
\hline \multirow[t]{9}{*}{$\begin{array}{l}\text { Food safety knowledge and } \\
\text { awareness* }\end{array}$} & $\begin{array}{l}\text { No knowledge and } \\
\text { awareness }\end{array}$ & 23.0 & 16.9 & \\
\hline & $\begin{array}{l}\text { With knowledge and no } \\
\text { awareness }\end{array}$ & 20.5 & 31.9 & \\
\hline & Avian influenza & 32.5 & 29.7 & \\
\hline & Newcastle disease & 8.5 & 6.1 & \\
\hline & Antibiotic & 0.9 & 1.6 & \\
\hline & Hormone & 0.9 & - & \\
\hline & Bacteria & 7.7 & 3.2 & $\begin{array}{r}1 \text { able } 4 . \\
4\end{array}$ \\
\hline & Formalin (preservatives) & 3.4 & 5.8 & $\begin{array}{l}\text { Soclodemographic } \\
\text { characteristics in }\end{array}$ \\
\hline & Others & 2.6 & 4.8 & modern and traditional \\
\hline \multicolumn{4}{|c|}{ Note(s): *The respondents could choose multiple responses } & channels \\
\hline
\end{tabular}

purchase poultry meat since in most families. The most common age of the respondents was 31-40 years old. The respondents' educational level showed that more than $50 \%$ of the respondents in both sales channels went to senior high school. However, no respondents obtained only primary school education in the modern channel. The comparison of income groups showed that the income of most respondents in the modern channel was over $€ 190$ per month, whereas that in the traditional channels was between $€ 105$ and $€ 148$ per month. Table 4 also shows that the number of respondents who had food safety knowledge but were unaware of food safety hazards was smaller in the modern channel than in the traditional channel $(20.5 \%$ vs $31.9 \%$, respectively). In both sales channels, the respondents who were knowledgeable and aware of food safety hazards most commonly considered avian influenza as food safety hazards ( $32.5 \%$ and $29.7 \%$, respectively).

\subsection{The MNL model estimation}

Table 5 presents the MNL models' estimation with the choice of freshness, FSC and product information label attributes in the modern and traditional channels. In both model estimations, a likelihood ratio test rejected the hypothesis of all coefficients that are zero. Hence, all coefficients were statistically significant at $1 \%(\phi<0.01)$. The coefficients in both models of the alternative-specific constants were positive (choices A and B), indicating that 


\begin{tabular}{|c|c|c|c|c|c|c|c|c|c|}
\hline \multirow{3}{*}{$\begin{array}{l}\text { BFJ } \\
123,13\end{array}$} & & & & & & & & & \\
\hline & \multicolumn{5}{|c|}{ Modern channel } & \multicolumn{4}{|c|}{ Traditional channel } \\
\hline & Coefficients & Estimates & $\begin{array}{l}\text { Std. } \\
\text { error }\end{array}$ & $\begin{array}{c}T- \\
\text { values }\end{array}$ & $\begin{array}{c}p- \\
\text { values }\end{array}$ & Estimates & $\begin{array}{l}\text { Std. } \\
\text { error }\end{array}$ & $\begin{array}{c}T- \\
\text { values }\end{array}$ & $\begin{array}{c}p- \\
\text { values }\end{array}$ \\
\hline & Choice A & 3.2571 & 0.0857 & 38.01 & 0.0000 & 3.9842 & 0.0651 & 41.2 & 0.0000 \\
\hline & Choice B & 3.5831 & 0.0415 & 43.64 & 0.0000 & 3.1526 & 0.0543 & 58.06 & 0.0000 \\
\hline \multirow[t]{11}{*}{538} & \multicolumn{9}{|l|}{ Freshness } \\
\hline & $\begin{array}{l}\text { - Warm } \\
\text { - Chilled }\end{array}$ & $\begin{array}{l}2.1974 \\
3.6851\end{array}$ & $\begin{array}{l}0.0652 \\
0.0436\end{array}$ & $\begin{array}{l}33.7 \\
22.65\end{array}$ & $\begin{array}{l}0.0000 \\
0.0000\end{array}$ & $\begin{array}{l}3.2575 \\
2.9341\end{array}$ & $\begin{array}{l}0.0632 \\
0.0578\end{array}$ & $\begin{array}{l}51.54 \\
43.29\end{array}$ & $\begin{array}{l}0.0000 \\
0.0000\end{array}$ \\
\hline & - Frozen & 2.5374 & 0.0369 & 47.28 & 0.0000 & 2.8475 & 0.0491 & 39.43 & 0.0000 \\
\hline & \multicolumn{9}{|c|}{ Food safety certification } \\
\hline & - Government & 1.3523 & 0.0563 & 24.02 & 0.0000 & 1.1562 & 0.0481 & 24.04 & 0.0000 \\
\hline & - Private & 1.2346 & 0.0299 & 34.61 & 0.0000 & 2.3256 & 0.0274 & 32.45 & 0.0000 \\
\hline & $\begin{array}{l}\text { - } \begin{array}{l}\text { No } \\
\text { certification }\end{array}\end{array}$ & 2.3371 & 0.0681 & 29.94 & 0.0000 & 2.4587 & 0.0342 & 31.87 & 0.0000 \\
\hline & \multicolumn{9}{|c|}{ Product label information } \\
\hline & - With label & 1.9576 & 0.0713 & 27.69 & 0.0000 & 0.5876 & 0.0639 & 9.2 & 0.0000 \\
\hline & $\begin{array}{l}\text { - Without } \\
\text { label }\end{array}$ & 2.3687 & 0.0391 & 39.71 & 0.0000 & 0.4852 & 0.0437 & 31.45 & 0.0000 \\
\hline & $\begin{array}{l}\text { Price } \\
N\end{array}$ & $\begin{array}{l}-0.6342 \\
1.521\end{array}$ & 0.0074 & -53.58 & 0.0000 & $\begin{array}{l}-0.7841 \\
4.069\end{array}$ & 0.0064 & -49.89 & 0.0000 \\
\hline & Log likelihood & -814.378 & & & & -2338.51 & & & \\
\hline del estimates & $X^{2}$ & 917.845 & & & & 2455.431 & & & \\
\hline
\end{tabular}

Note(s): The alternative-specific constants (CHOICE A and CHOICE B) are estimated to indicate the utility of each option relative to the no-buying option

the consumers' utility for options A and B is higher than for no-buying option (choice C) in both sales channels. Consequently, consumers of poultry meat at a constant price prefer buying poultry meat to not buying at all. Therefore, freshness, FSC and product information label attributes were relevant for the poultry meat consumers in both sales channels. Clearly, the likelihood of purchase is shown by the negative coefficient for the price in both models. It demonstrates that the consumer's utility in poultry meat will decrease with increased prices at both sales channels.

\subsection{Consumer WTP for the chosen attributes}

The consumers' WTP for each chosen attribute is presented in Table 6. These findings are statistically significant at the 5\% level. All attributes in modern and traditional channels have a positive premium. The WTP for the freshness attribute showed that respondents in both channels had a higher WTP for warm poultry meat than for chilled or frozen poultry meat. In particular, respondents in the traditional channel had a higher WTP for warm and frozen poultry meat than respondents in the modern channel. Respondents in the modern channel had a higher WTP for chilled poultry meat than respondents in the traditional channel. The WTP for the FSC attribute showed that respondents in both sales channels were willing to pay more for government certification than for private certification or no certification. Respondents in the traditional channel had a higher WTP for government or no certification than respondents in the modern channel. By contrast, respondents in the modern channel had higher WTP for private certification than those in the traditional channel. Lastly, the respondents in both sales channels had a higher WTP for poultry meat with a product information label than for poultry meat without a product information label. Respondents in the modern channel had a higher WTP for poultry meat with a product information label than respondents in the traditional channel. 


\section{Discussion}

Focusing on a higher level of control in the market will lead to a lower food safety problem (Indrawan and Daryanto, 2020). Many studies posited that HPAI cases or other food unsafety incidents would be reduced by removing the traditional market entirely. This option was impossible due to the number of people involved and the economic cost and impact. Therefore, alongside Food and Agriculture Organization and many other related projects, the government chooses to improve food safety in the traditional sales channel by introducing FSC and building consumers' awareness of chilled and frozen poultry meat. By following this strategy, we examined the possible product choices to intervene in the consumers' preference to lower the HPAI cases and reduce sick poultry entering the live bird markets. In this study, we carried out a discrete choice experiment to obtain insight into Indonesian consumers' preferences for poultry meat attributes and WTP related to food safety. Although such a research setup provides many outcomes and significant relations, two main findings stand out: consumers have a high preference for warm poultry meat and have a higher trust in a governmental certification system than in a private system.

Although we only examined the three food safety attributes, we found important insights into the attributes and WTP. The preference and WTP showed the importance of the experience quality attribute for consumers for freshness level as the nonfood safety attribute for poultry meat. We found that the preference and WTP for warm poultry meat were much higher than chilled and frozen poultry meat in both poultry sales channels. For the consumers interviewed at the wet market, this might be logical; however, consumers interviewed in the modern market preferred warm poultry meat. This finding means that consumers in the modern channel, who experienced buying poultry meat in the traditional channel, may choose warm poultry meat if the modern channel provides this type of poultry meat. This observation supports previous work suggesting that in certain countries, consumers relate the term freshness to freshly cut (a short time between slaughter and sales) (Chamhuri et al., 2015; Goldman and Hino, 2005; Indrawan et al., 2018b; Zhang, 2003). This finding brings a dilemma, because, although warm poultry is perceived as a quality cue in terms of freshness, it is assumed to be less safe (Indrawan et al., 2018a). The results also show that the consumers' WTP for chilled and frozen poultry meat is related to food safety awareness. This outcome may be the consequence of an ongoing government program in Indonesia aimed at increasing food safety awareness by promoting these types of meats (Sparringa, 2014). It means the government efforts may have had an effect and that this program should be continued to further increase the awareness of food safety hazards.

\begin{tabular}{lccc}
\hline Attributes & Modern channel & Traditional channel & Pooled sampled \\
\hline $\begin{array}{l}\text { Freshness } \\
\text { - Warm }\end{array}$ & $2.64(0.129)$ & $2.83(0.131)$ & \\
- Chilled & $2.22(0.132)$ & $2.01(0.122)$ & $2.83(0.131)$ \\
- Frozen & $2.30(0.145)$ & $2.33(0.152)$ & $2.34(0.118)$ \\
Food safety certification & & & \\
- Government & $2.68(0.133)$ & $2.73(0.149)$ & $2.71(0.146)$ \\
- Private & $2.14(0.112)$ & $2.05(0.105)$ & $2.04(0.101)$ \\
- No certification & $2.29(0.151)$ & $2.39(0.167)$ & $2.38(0.166)$ \\
Product information label & & & \\
- With label & $2.49(0.157)$ & $2.42(0.151)$ & $2.40(0.149)$ \\
- Without label & $2.25(0.147)$ & $2.36(0.149)$ & $2.35(0.148)$
\end{tabular}

Note(s): Significant of $5 \%$ level. Standard deviation in parentheses
Improving poultry meat and sales channels

539
Table 6 Mean and standard deviation of WTP estimates of the MNL estimates $(€ / \mathrm{kg})$


BFJ

123,13

540

We explored the possibilities of increasing the level of food safety in poultry meat consumption; therefore we also examined FSC and product information labels as food safety attributes for poultry meat. Although many recent studies have suggested that the role of thirdparty certification is increasing (Albersmeier et al., 2009; Qijun and Batt, 2016; Simmons, 2010), we found that the consumers in both sales channels (traditional and modern) had a higher preference for government certification. In addition, Wahida et al. (2013) found that Indonesian consumers trusted government certification more. In combination with FSC, consumers in both poultry sales channels perceived the product information label as a vital quality cue. The preference for poultry meat with a product information label was higher than that without a product information label. This finding agrees with other studies (Stranieri and Banterle, 2015; Verbeke and Ward, 2006; Wahida et al., 2013). It suggests that consumers require more information about poultry meat before they purchase it (Font-i-Furnols and Guerrero, 2014; Makanyeza et al., 2016). However, the results may seem peculiar for consumers in the traditional market, because no such product information label exists currently in this channel. The preference may stem from increased consumer food safety awareness. Moreover, because of many food unsafety incidents, consumers' trust in the salesperson in the traditional channel may be decreasing. Further research is needed to uncover the underlying reasons.

Finally, the consumers' WTP in two sales channels shows that consumers consider their WTP for a certain attribute for better quality based on the value for money (Chamhuri and Batt, 2013). In the modern channel, consumers had a higher WTP for government certification than for other poultry meat attributes. However, in the traditional channel, consumers had higher WTP for warm poultry meat. This finding means that consumers in these two sales channels evaluate quality based on different values. Consumers in the modern channel rely on government certification to ensure poultry meat quality, whereas those consumers in the traditional channel rely on their own experience. The results reinforce previous studies showing that price is an important instrument to signal consumers about the value of a product (Chamhuri et al., 2015; Cicia and Colantuoni, 2010). Therefore, prices can play a role as drivers of consumer preferences for a certain poultry meat attribute. Hence, by utilizing the simple effect of own price on consumer demand, the government can influence consumers' WTP for the preferred attributes by subsidies and/or taxes in sales channels (Indrawan et al., 2019). In Indonesia, regional government-applied taxes for animal trade were applied at the animal market in the form of local taxes and retribution. Since early 2000, when Indonesia began regional autonomy, taxes in regional markets serve as regional government source of income. By setting up a tax system for less-safe poultry in the traditional channel, poultry meat could become more expensive. By contrast, reducing taxes or increasing subsidies for poultry meat with preferable food safety attributes in the modern channel will make it more attractive for consumers to buy safer poultry meat. Such subsidies in Indonesia could utilize the food subsidy scheme for low-income households; the local government often provides this scheme in the form of price intervention during several events. This action may affect poultry consumers' preferences and buying behavior. However, if consumers truly use price as a quality signal, the taxed product would signal more quality to consumers, offsetting part of the own-price effect. Likewise, a subsidy will signal lower quality, offsetting part of the subsidy's own-price effect. Nevertheless, this effect will be less apparent in low-income countries, because the consumers are price-sensitive and are not concerned with safety attributes (Röhr et al., 2005).

Attention should be given to the food safety awareness findings that were collected by open questions. Salmonella contamination was reported as the most important foodborne pathogen causing diarrhea in Indonesia, with (probably underestimated) the prevalence of 358-810 cases per 100,000 Indonesians per year (Kusumaningrum et al., 2012). However, the respondents' awareness of avian influenza exceeded bacteria (Campylobacter, $L$ monocytogenes, $C$ perfringens and E. coli O157): only $3.2 \%-7.7 \%$ of the respondents 
expressed awareness of bacteria as a food safety problem. Indonesian consumers seem to be unaware of bacteria as a food safety problem because less attention is paid to them than the avian influenza outbreak by national mass media.

This study was primarily designed to generate insight into the consumers' choice and their WTP for poultry attributes in a specific sales channel rather than explaining their choice. We did not consider the factors that motivate or demotivate consumers in purchasing poultry meat, such as religion and/or ethnicity, a presence of a domestic assistant and/or their role in shopping for food and attitudinal variables (e.g. trust in certifying body and concerns about food safety). In the future, studies combining techniques from social-psychology with knowledge about poultry purchasing behavior could be useful. Several behavioral-type theories (e.g. theory of planned behavior, theory of reasoned action and hierarchy of effects, etc.) in social psychology are worthwhile exploring. These theories could establish a better causal and conceptually more logical relationship in determining WTP as an outcome.

In general, this study implies that a pull strategy is needed to lower the HPAI cases by improving the sales channel (Indrawan et al., 2019). A pull strategy can be implemented by a policy to change consumer preferences through campaigns such as education and promotion of healthy poultry meat. Campaigns as pull strategies include mass media promotions, wordof-mouth referrals and advertised sales promotions. The campaign's goal is to increase healthy meat product loyalty and keep customers returning. Campaigns may be more effective if the government intervenes with financial incentives. The study was conducted in western Java, especially in Greater Jakarta; thus, the intervention strategy such as taxes and subsidies can be set as an example to improve the sales channel for other regions in Indonesia and in Southeast Asia countries. Greater Jakarta is a metropolitan area, so its residents are more educated and sensitive to price changes than those in other areas. Furthermore, Greater Jakarta is the center of economic growth in Indonesia, and it is the primary market for many products. Thus, as the primary market, Greater Jakarta sets the consumer trend in Indonesia. Consumers in Greater Jakarta should understand the existence of food unsafety in warm poultry meat. Changes in consumers' preferences for poultry meat by demanding chilled or frozen, food safety certified and labeled poultry meat will improve food safety in the sales channel in Greater Jakarta. This intervention strategy that raises the food safety standards will support the government's objective to shift sales channels from traditional to modern channels. Moreover, the consumers in Greater Jakarta are expected to start demanding a higher meat quality and influence other consumers in Indonesia. Simultaneously, producers will respond to the increasing demand for higher-quality meat to move toward better production and biosecurity. Therefore, the traditional sales channel will improve and become more modern to serve safe poultry meat. Thus, as the traditional sales channel will no longer exist, the meat producers and/or the farmers will start labeling their meats and using FSC to compete in the modern markets. Finally, the value for money of better-quality meat will give benefits to consumers and producers. In the context of public health, the value for money for better poultry meats will reduce the incidents of food unsafety and the HPAI outbreaks.

\section{Conclusion}

Indonesian consumers, including consumers in Greater Jakarta, see poultry meat's freshness as an important attribute that ensures poultry meat quality. The WTP for warm poultry was the highest of three preferred poultry meat attributes (i.e. warm poultry meat, government certification and product information label). It is also the main attribute for consumers who are buying poultry meat in the traditional channel. Poultry meat's freshness is still very important for those who buy in the modern channel, but WTP for government certification is slightly higher than WTP for warm poultry meat. The findings imply that government intervention will raise food safety standards that match consumers' preferences to lower the HPAI cases and reduce sick poultry entering live bird markets. To have consumers direct the

\section{Improving poultry meat and sales channels}


BFJ 123,13

market to a safer production of poultry, the government can use a price-setting mechanism (e.g. subsidies and/or taxes) and/or advertise and promote food safety to increase WTP for a certain attribute. This price-setting mechanism should be integrated into the local government taxes and subsidies program. Therefore, the government should work on the integration of these mechanisms in their food and health policymaking and implementation. The study did not consider the factors that motivate or demotivate consumers to purchase poultry meat; therefore, studies combining techniques from social psychology with knowledge about poultry purchasing behavior could be useful.

\section{References}

Albersmeier, F., Schulze, H., Jahn, G. and Spiller, A. (2009), "The reliability of third-party certification in the food chain: from checklists to risk-oriented auditing", Food Control, Vol. 20 No. 10, pp. 927-935, doi: 10.1016/j.foodcont.2009.01.010.

Angulo, A.M. and Gil, J.M. (2007), "Risk perception and consumer willingness to pay for certified beef in Spain", Food Quality and Preference, Vol. 18 No. 8, pp. 1106-1117, doi: 10.1016/j.foodqual. 2007.05.008.

Bahri, S. (2008), "Some aspects of food safety for animal based products in Indonesia (in Bahasa)", Pengembangan Inovasi Pertanian, Vol. 1 No. 3, pp. 225-242.

Bett, H.K., Peters, K.J., Nwankwo, U.M. and Bokelmann, W. (2013), "Estimating consumer preferences and willingness to pay for the underutilised indigenous chicken products", Food Policy, Vol. 41, pp. 218-225, doi: 10.1016/j.foodpol.2013.05.012.

Castellini, C., Berri, C., Le Bihan-Duval, E. and Martino, G. (2008), "Qualitative attributes and consumer perception of organic and free-range poultry meat", World's Poultry Science Journal, Vol. 64 No. 4, pp. 500-512, doi: 10.1017/S0043933908000172.

Chamhuri, N. and Batt, P.J. (2013), "Understanding the relationship between perceived quality cues and quality attributes in the purchase of meat in Malaysia", Journal of International Food and Agribusiness Marketing, Vol. 25 No. 3, pp. 187-208, doi: 10.1080/08974438.2013.723999.

Chamhuri, N., Kusumawaty, Y. and Batt, P.J. (2015), "Consumers' purchasing behaviour for fresh meat from modern retail stores and traditional markets in Malaysia and Indonesia", Islamic Perspectives on Marketing and Consumer Behavior: Planning, Implementation, and Control, IGI Global, pp. 72-102, doi: 10.4018/978-1-4666-8139-2.ch004.

Chrzan, K. and Orme, B. (2000), "An overview and comparison of design strategies for choice-based conjoint analysis", Sawtooth Software Research Paper Series 98382, available at: https://www. academia.edu/download/41021413/desgncbc.pdf (accessed 10 October 2016).

Cicia, G. and Colantuoni, F. (2010), "Willingness to pay for traceable meat attributes: a meta-analysis", International Journal on Food System Dynamics, Vol. 1 No. 3, pp. 252-263, doi: 10.18461/ijfsd. v1i3.138.

Daryanto, A., de Boer, D., Indrawan, D., Leenstra, F., Mudde, H., Fahmi, I. and van Horne, P. (2014), "Socio-economic analysis of the slaughtering systems in the poultry meat sector in Greater Jakarta area", available at: http://www.difslive.com/wp-content/uploads/2015/08/Annex-BSocio-economic-survey-slaugther-process.pdf (accessed February 2016).

Fardiaz, D., Bhat, R. and Sareen, S. (2011), "Guidelines for risk categorization of food and food establishments applicable to ASEAN countries”, RAP Publication (FAO) eng no. 2011/22, available at: https://agris.fao.org/agris-search/search.do?recordID=XF2017002194 (accessed 14 February 2016).

Fletcher, D. (2002), "Poultry meat quality”, World’s Poultry Science Journal, Vol. 58 No. 2, pp. 131-145, doi: 10.1079/WPS20020013.

Font-i-Furnols, M. and Guerrero, L. (2014), "Consumer preference, behavior and perception about meat and meat products: an overview”, Meat Science, Vol. 98 No. 3, pp. 361-371, doi: 10.1016/j.meatsci. 2014.06.025. 
Goldman, A. and Hino, H. (2005), "Supermarkets vs. traditional retail stores: diagnosing the barriers to supermarkets' market share growth in an ethnic minority community", Journal of Retailing and Consumer Services, Vol. 12 No. 4, pp. 273-284, doi: 10.1016/j.jretconser.2004.10.002.

Goldman, A., Krider, R. and Ramaswami, S. (1999), "The persistent competitive advantage of traditional food retailers in Asia: wet markets' continued dominance in Hong Kong", Journal of Macromarketing, Vol. 19 No. 2, pp. 126-139, doi: 10.1177/0276146799192004.

Grunert, K.G. (2005), "Food quality and safety: consumer perception and demand”, European Review of Agricultural Economics, Vol. 32 No. 3, pp. 369-391, doi: 10.1093/eurrag/jbi011.

Grunert, K.G., Bredahl, L. and Brunsø, K. (2004), "Consumer perception of meat quality and implications for product development in the meat sector-a review", Meat Science, Vol. 66 No. 2, pp. 259-272, doi: 10.1016/S0309-1740(03)00130-X.

Hariyadi, P. (2008), "Double challenges; food safety problems in Indonesia (in Bahasa)", Jurnal Pangan, Vol. 17 No. 2, pp. 17-27, doi: 10.33964/jp.v17i2.249.

Henchion, M., McCarthy, M., Resconi, V.C. and Troy, D. (2014), "Meat consumption: trends and quality matters", Meat Science, Vol. 98 No. 3, pp. 561-568, doi: 10.1016/j.meatsci.2014.06.007.

Hoffmann, R. (2000), "Country of origin-a consumer perception perspective of fresh meat", British Food Journal, Vol. 102 No. 3, pp. 211-229, doi: 10.1108/00070700010332304.

Hu, W., Batte, M.T., Woods, T. and Ernst, S. (2011), "Consumer preferences for local production and other value-added label claims for a processed food product", European Review of Agricultural Economics, Vol. 39 No. 3, pp. 489-510, doi: 10.1093/erae/jbr039.

Indrawan, D. and Daryanto, A. (2020), "Food control and biosecurity roles in the global value chain: supporting producers or safeguarding consumers?", IOP Conference Series: Earth and Environmental Science, IOP Publishing, Vol. 519 No. 1, 012040, doi: 10.1088/1755-1315/519/1/ 012040.

Indrawan, D., Rich, K.M., van Horne, P., Daryanto, A. and Hogeveen, H. (2018a), "Linking supply chain governance and biosecurity in the context of HPAI control in Western Java: a value chain perspective", Frontiers in Veterinary Science, Vol. 5, p. 94, doi: 10.3389/fvets.2018.00094.

Indrawan, D., Tacken, G. and Hogeveen, H. (2018b), "What drives the choice of poultry market channel and the change of purchase behavior due to highly pathogenic avian influenza outbreaks?”, Poultry Science, Vol. 97 No. 10, pp. 3652-3660, doi: 10.3382/ps/pey222.

Indrawan, D., Stegeman, A., Daryanto, A. and Hogeveen, H. (2019), "A push and pull intervention to control avian influenza: a lesson learned from the western java poultry sector", Jurnal Manajemen and Agribisnis, Vol. 16 No. 3, p. 179, doi: 10.17358/jma.16.3.179.

Issanchou, S. (1996), "Consumer expectations and perceptions of meat and meat product quality", Meat Science, Vol. 43, pp. 5-19, doi: 10.1016/0309-1740(96)00051-4.

Kehagia, O., Linardakis, M. and Chryssochoidis, G. (2007), "Beef traceability: are Greek consumers willing to pay?”, EuroMed Journal of Business, Vol. 2 No. 2, pp. 173-190, doi: 10.1108/ 14502190710826040.

Kehlbacher, A., Bennett, R. and Balcombe, K. (2012), "Measuring the consumer benefits of improving farm animal welfare to inform welfare labelling”, Food Policy, Vol. 37 No. 6, pp. 627-633, doi: 10. 1016/j.foodpol.2012.07.002.

Kennedy, O.B., Stewart-Knox, B., Mitchell, P. and Thurnham, D. (2004), "Consumer perceptions of poultry meat: a qualitative analysis", Nutrition \& Food Science, Vol. 34 No. 3, pp. 122-129, doi: 10.1108/00346650410536746.

Kiilholma, J. (2008), "Food-safety concerns in the poultry sector of developing countries", Proceedings of the International Conference Poultry in the Twenty-first Century: avian influenza and beyond, Rome, FAO.

Kuhfeld, W.F. (1997), "Efficient experimental designs using computerized searches”, Research Paper Series, SAS Institute, Provo.

\section{Improving \\ poultry meat and sales channels}


BFJ 123,13

\section{4}

Kuhfeld, W.F. (2005), "Marketing research methods in SAS. Experimental design, choice, conjoint, and graphical techniques", Cary, NC, SAS-Institute TS-722, available at: http://support. sas. com/ techsup/technote/ts694. pdf (Accessed 10 October 2016).

Kusumaningrum, H. and Dewanti-Hariyadi, R. (2012), "Multidrug resistance among different serotypes of Salmonella isolates from fresh products in Indonesia”, International Food Research Journal (Malaysia), Vol. 19 No. 1, pp. 57-63.

Lancaster, K.J. (1966), "A new approach to consumer theory”, Journal of Political Economy, Vol. 74 No. 2, pp. 132-157, doi: 10.1086/259131.

Lestari, V.S., Natsir, A., Karim, H. and Patrick, I. (2016), "Factors affecting consumers' willingness to pay for chicken meat from biosecure farms", World Academy of Science, Engineering and Technology, International Science Index, Economics and Management Engineering, Vol. 10 No. 6, p. 2242.

Loureiro, M.L. and Umberger, W.J. (2007), "A choice experiment model for beef: what US consumer responses tell us about relative preferences for food safety, country-of-origin labeling and traceability”, Food Policy, Vol. 32 No. 4, pp. 496-514, doi: 10.1016/j.foodpol.2006.11.006.

Makanyeza, C., Macheyo, R. and du Toit, F. (2016), "Perceived product necessity, perceived value, customer satisfaction and affective attitude: an integrative model", Journal of African Business, Vol. 17 No. 1, pp. 69-86, doi: 10.1080/15228916.2016.1112709.

Martínez Michel, L., Anders, S. and Wismer, W.V. (2011), "Consumer Preferences and willingness to pay for value-added chicken product attributes", Journal of Food Science, Vol. 76 No. 8, pp. S469-S477.

Maynard, L.J., Burdine, K.H. and Meyer, A.L. (2003), "Market potential for locally produced meat products”, Journal of Food Distribution Research, Vol. 34, pp. 26-37, doi: 10.1111/j.1750-3841. 2011.02354.x.

McFadden, D. (2001), "Economic choices”, American Economic Review, Vol. 91 No. 3, pp. 351-378, doi: 10.1257/aer.91.3.351.

Mead, G. (2004), "Microbiological quality of poultry meat: a review", Revista Brasileira de Ciência Avícola, Vol. 6 No. 3, pp. 135-142, doi: 10.1590/S1516-635X2004000300001.

Meredith, H., Walsh, D., McDowell, D.A. and Bolton, D.J. (2013), “An investigation of the immediate and storage effects of chemical treatments on Campylobacter and sensory characteristics of poultry meat", International Journal of Food Microbiology, Vol. 166 No. 2, pp. 309-315, doi: 10. 1016/j.ijfoodmicro.2013.07.005.

Meuwissen, M.P., Velthuis, A.G., Hogeveen, H. and Huirne, R.B. (2003), "Traceability and certification in meat supply chains", Journal of Agribusiness, Vol. 21 No. 2, pp. 167-181, doi: 10.22004/ag. econ.14666.

Muladno, M. and Thieme, O. (2009), "Consumer preferences for poultry in Indonesia”, GCP/RAS/228/ GERWorking paper, available at: https://www.fao.org/3/al700e/al700e.pdf (accessed 13 January 2016).

Ortega, D.L., Wang, H.H., Wu, L. and Olynk, N.J. (2011), "Modeling heterogeneity in consumer preferences for select food safety attributes in China", Food Policy, Vol. 36 No. 2, pp. 318-324, doi: 10.1016/j.foodpol.2010.11.030.

Owusu-Sekyere, E., Owusu, V. and Jordaan, H. (2014), "Consumer preferences and willingness to pay for beef food safety assurance labels in the Kumasi Metropolis and Sunyani Municipality of Ghana”, Food Control, Vol. 46, pp. 152-159, doi: 10.1016/j.foodcont.2014.05.019.

PINSAR (2016), "Info Harga", available at: http://pinsarindonesia.com/info-harga/ (accessed 10 October 2016).

Probst, L., Houedjofonon, E., Ayerakwa, H.M. and Haas, R. (2012), "Will they buy it? The potential for marketing organic vegetables in the food vending sector to strengthen vegetable safety: a choice experiment study in three West African cities”, Food Policy, Vol. 37 No. 3, pp. 296-308, doi: 10.1016/j.foodpol.2012.02.014. 
Qijun, J. and Batt, P.J. (2016), "Barriers and benefits to the adoption of a third party certified food safety management system in the food processing sector in Shanghai, China", Food Control, Vol. 62, pp. 89-96, doi: 10.1016/j.foodcont.2015.10.020.

Röhr, A., Lüddecke, K., Drusch, S., Müller, M.J. and Alvensleben, R.v. (2005), "Food quality and safety-consumer perception and public health concern", Food Control, Vol. 16 No. 8, pp. 649-655, doi: 10.1016/j.foodcont.2004.06.001.

Rousseau, S. and Vranken, L. (2013), "Green market expansion by reducing information asymmetries: evidence for labeled organic food products”, Food Policy, Vol. 40, pp. 31-43, doi: 10.1016/j. foodpol.2013.01.006.

Samant, S.S. and Seo, H.S. (2016), "Quality perception and acceptability of chicken breast meat labeled with sustainability claims vary as a function of consumers' label-understanding level”, Food Quality and Preference, Vol. 49, pp. 151-160, doi: 10.1016/j.foodqual.2015.12.004.

Scallan, E., Hoekstra, R.M., Angulo, F.J., Tauxe, R.V., Widdowson, M.A., Roy, S.L., Jones, J.L. and Griffin, P.M. (2011), "Foodborne illness acquired in the United States-major pathogens", Emerging Infectious Diseases, Vol. 17 No. 1, pp. 7-15, doi: 10.3201/eid1701.P11101.

Schleenbecker, R. and Hamm, U. (2013), “Consumers' perception of organic product characteristics. A review", Appetite, Vol. 71, pp. 420-429, doi: 10.1016/j.appet.2013.08.020.

Scott, E. (2003), "Food safety and foodborne disease in the 21st Century", Canadian Journal of Infectious Diseases and Medical Microbiology, Vol. 14, pp. 277-280, doi: 10.1155/2003/363984.

Simmons, H. (2010), "National and international food safety certification schemes", in Bratt, L (Ed.), Fish Canning Handbook, Wiley-Blackwell, NJ, pp. 85-101.

Slovin, E. (1960), "Slovin's formula for sampling technique”, available at: https://prudencexd.weebly. $\mathrm{com} /$ (accessed 13 February 2013).

Souza, A.P.O., Sans, E.C.D.O., Müller, B.R. and Molento, C.F.M. (2015), "Broiler chicken welfare assessment in GLOBALGAP ${ }^{2}$ certified and non-certified farms in Brazil", Animal Welfare, Vol. 24 No. 1, pp. 45-54, doi: 10.7120/09627286.24.1.045.

Sparringa, R. (2014), "Food safety for animal based product in Indonesia (in Bahasa)", Proceedings of National Seminar on World Food Day XXVII, Jakarta, Badan Penelitian dan Pengembangan Pertanian, pp. 55-67.

Statistics-Bureau, I. (2016), “Statistical yearbook of Indonesia 2016”, available at: https://www. bps.go.id/website/pdf_publikasi.Statistik-Indonesia-2016-_rev.pdf (accessed 30 December 2016).

Stranieri, S. and Banterle, A. (2015), "Consumer interest in meat labelled attributes: who cares?", The International Food and Agribusiness Management Review, Vol. 18 No. 4, pp. 21-38, doi: 10.22004/ ag.econ.211652.

Trienekens, J. and Zuurbier, P. (2008), "Quality and safety standards in the food industry, developments and challenges", International Journal of Production Economics, Vol. 113 No. 1, pp. 107-122, doi: 10.1016/j.jpe.2007.02.050.

Van Loo, E.J., Caputo, V., Nayga, R.M., Meullenet, J.F. and Ricke, S.C. (2011), “Consumers’ willingness to pay for organic chicken breast: evidence from choice experiment", Food Quality and Preference, Vol. 22 No. 7, pp. 603-613, doi: 10.1016/j.foodqual.2011.02.003.

Verbeke, W. and Viaene, J. (1999), "Beliefs, attitude and behaviour towards fresh meat consumption in Belgium: empirical evidence from a consumer survey", Food Quality and Preference, Vol. 10 No. 6, pp. 437-445, doi: 10.1016/S0950-3293(99)00031-2.

Verbeke, W.A.J. and Viaene, J. (2000), "Ethical challenges for livestock production: meeting consumer concerns about meat safety and animal welfare", Journal of Agricultural and Environmental Ethics, Vol. 12, pp. 141-151, doi: 10.1023/A:1009538613588.

Verbeke, W. and Ward, R.W. (2006), "Consumer interest in information cues denoting quality, traceability and origin: an application of ordered probit models to beef labels", Food Quality and Preference, Vol. 17 No. 6, pp. 453-467, doi: 10.1016/j.foodqual.2005.05.010. 
$\mathrm{BFJ}$

123,13

\section{6}

Wahida, Toiba, H., Umberger, W.J. and Minot, N. (2013), "Exploring Indonesian consumers' willingness to pay for high-value agricultural products", Paper presented at the Acta Horticulturae. In IV International Symposium on Improving the Performance of Supply Chains in the Transitional Economies, Vol. 1006, pp. 397-404, doi: 10.17660/ActaHortic.2013. 1006.50.

Wongprawmas, R. and Canavari, M. (2017), “Consumers' willingness-to-pay for food safety labels in an emerging market: the case of fresh produce in Thailand", Food Policy, Vol. 69, pp. 25-34, doi: 10.1016/j.foodpol.2017.03.004.

Wu, L., Wang, H., Zhu, D., Hu, W. and Wang, S. (2016), “Chinese consumers' willingness to pay for pork traceability information-the case of Wuxi”, Agricultural Economics, Vol. 47 No. 1, pp. 71-79, doi: 10.1111/agec.12210.

Yeung, R.M. and Morris, J. (2001), "Food safety risk: consumer perception and purchase behavior", British Food Journal, Vol. 103 No. 3, pp. 170-187, doi: 10.1108/00070700110386728.

Zhang, X. (2003), "The dynamics of Chinese consumers: a case of Shanghai food consumption", Journal of International Food and Agribusiness Marketing, Vol. 14 No. 1, pp. 47-66, doi: 10.1300/ J047v14n01_04.

\section{Corresponding author}

Dikky Indrawan can be contacted at: rdikky@apps.ipb.ac.id

For instructions on how to order reprints of this article, please visit our website: 